\title{
Examination of Changes in Certain Biochemical Parameters Before and After Acute Training in Kick Boxers
}

\author{
Mustafa Karadağ ${ }^{1}$, Ercan Gür ${ }^{1}$, Kürşat Kargün ${ }^{1}$, Yüksel Savucu ${ }^{1}$, Gülbin Eskiyecek ${ }^{2}$ \\ ${ }^{1}$ Faculty of Sport Sciences, Firat University, Elazı ğ, Turkey \\ ${ }^{2}$ School of Physical Education, Artuklu University, Mardin, Elazığ, Turkey \\ Correspondence: Mustafa KARADAĞ, Faculty of Sport Sciences, Firat University, 23119-Elazı̆̆, Turkey.
}

Received: August 1, 2018

doi:10.11114/jets.v6i12.3506
Online Published: November 26, 2018

URL: https://doi.org/10.11114/jets.v6i12.3506

\begin{abstract}
Kickbox is one of the modern martial sports. The psychophysiological demands of a kickbox competition require that athletes achieve high thresholds in various aspects of physical fitness.

The aim of this study is to analyze and evaluate the physiological properties of kickbox athletes and the activity profile properly in order to put forward proposals for training and new scientific research fields. The blood samples, which were taken before and after the maximal training applied to athletes according to the period, were studied. A total of 50 athletes, including 39 male and 11 female amateurs, were included in the study, with an average age of $20.08 \pm 6.33$ years. All participants were informed about the study and necessary approvals. There was a significant difference between males and females in terms of BMI (Body Mass Index). It was observed that the GSH values of the athletes increased before and after training in both males and females. On the other hand, IL-1B (interleukin) only increased in males $(\mathrm{p}<0.05)$. The information obtained shows that the analyses of the before and after training male kickboxers at the amateur level are significantly more different than that of women. Since GSH is an effective tripeptide of antioxidants involved in the detoxification of harmful compounds, its synthesis is very important for metabolism. It can be said that GSH (glutathione) level may increase with normal exercise in daily life and training in athletes. Furthermore, the athletes should be analyzed metabolically well in response to the stress that may be caused by heavy exercise, and the exercise for improving performance should be achieved by detecting biochemical changes.
\end{abstract}

Keywords: Kickbox, training, GSH, TNF- $\alpha$, IL-1 $\beta$, IL-6

\section{Introduction}

Kickbox is a sport branch in which two athletes compete by an appropriate technique and speed to achieve the most score in accordance with the rules. When the punches and the kicks are tightly controlled, points are given when the hands or feet hit the allowed areas by appropriate techniques in accordance with the rules (Aykın, 2010). Because of its beneficial effects, such as personal protection, self-confidence, increasing muscle strength and retaining body form, the interest in kickbox sport is constantly increasing worldwide (Atabek, 2009). Due to the positive effects mentioned above, kickbox is recommended in terms of protecting the health and ensuring physical fitness. However, besides these positive effects, traumatic injuries and various physiological effects can be seen especially in martial arts, such as kickbox (Ouergui et al., 2013). Athletes should be carefully monitored during competitions not only because kickbox is physiologically complex, but also because the mechanistic and metabolic trait range has been used during competition. A number of studies have been carried out in order to examine the effects of these metabolic events on the performance of athletes. Especially the effects of different study programs during acute or chronic period on biochemical parameters have become the focus of many researchers (Bond et al., 1991; Karadağ, 2017). These scientific studies provide us with highly important information that is specific to the performed sport. It has been reported that blood parameters influence the type and intensity of the exercise, while exercise also affects blood parameters (Çavuşoğlu, 1991).

Glutamic acid, which is widely distributed in tissues in the liver and composed of cysteine and glycine, is an antioxidant effective tripeptide that is involved in the detoxification of harmful compounds by capturing epoxides, peroxides and other free radicals, in the form of reduced (GSH) and oxidized (GSSG). GSH (Glutathione) is present in millimolar concentrations in all mammalian cells and has various cellular functions, including amino acid transport, continuation of the reduction of sulfhydryl groups of proteins, protection against oxidative molecules and electrophilic xenobiotics. 
Glutamic acid has two forms, including reductive and oxidative (Dildar and Akçay, 1995). Glutathione is one of the strongest and most important antioxidants in our bodies. The glutathione, the manager of our entire immune system, is a substance that is synthesized in our body under normal conditions, but in some cases its level can decrease. When many radical substances such as leaked oxygen radicals are not neutralized by the anti-oxidant system in metabolism, they can lead to chronic diseases such as autoimmune diseases and cancer. In addition to healthy nutrition, staying away from ready-to-eat processed foods and sedentary lifestyle directly affects our physical and mental health. The function and maintenance of our muscles and internal organs is closely related to the diet as well as to the sports, and to prevent diseases and protect against the effects of aging, to control the immune system and chronic inflammation are related to maintain presence and high levels of antioxidant compounds such as glutathione. Studies have shown that increased glutathione levels reduce muscle damage, shortens the recovery time of muscles, increases muscle strength and endurance, and shifts metabolism to muscle formation without storing fat (http://www.drmuratkeklikoglu.com).

Interleukin 6 (IL-6) is a multifunctional helical cytokine that regulates cell proliferation and differentiation of various tissues, which are particularly well known for their role in immune response and acute phase reactions. The IL-6 protein is secreted by a variety of cell types, including T-cells and macrophages. The IL-6R complex has high affinity and therefore transduces the signals. IL-6 is associated with hematopoiesis, bone metabolism, and cancer progression, and is identified as an important role in directing the transition to innate immunity. IL-6 is a cytokine previously termed as 26-kDa protein, BCDF, BSF-2, cytotoxic T-cell differentiating factor, HSF, hybridoma/plasmocytic growth factor, IFN 32 , monocyte granulocyte-inducing type 2 and thrombopoietin (Abbas, 1994). The IL-1 innate immunity generated in macrophages mainly mediates the host inflammatory response. There are two forms, $\alpha$ and $\beta$, which exhibit indigenous biological activity. While it mediates local inflammation and allows the synthesis of leukocyte-activating chemokines from mononuclear phagocytes and endothelial cells at low concentrations, it participates in the bloodstream and acts like an endocrine hormone, showing the effects like TNF-like fever, hepatic acute phase proteins synthesis and cachexy at high concentrations (Callard and Gearing, 1994; Rosa and Pinto, 2006).

Cytokines are involved in the formation of inflammatory responses, particularly IL-1, TNF alpha and beta, IFN-gamma and chemokines. Cytokines can also have systemic effects as well as being effective on the cells that they were produced (autocrine effect) and on other nearby cells (paracrine action). Cytokines act by binding to their receptors on the target cell. Their half-lives are short and their effects occur in a limited period. A cytokine can increase the secretion and effect of another cytokine, as well as can inhibit them. The tumor necrosis factor alpha (TNF-alpha), also known as TNF, TNFA or TNFSF2, is a prototypic cytokine of TNF superfamily, and is a multifunctional molecule used in the regulation of a wide range of biological processes, including cell proliferation and differentiation. In our study, it was aimed to investigate the changes in some biochemical parameters before and after acute training in kick boxers considering that there will be receptor effects on possible lipid metabolism after sports activities (https://www.sinobiological.com/TNF-alpha-Protein-g-370.html) and heavy exercise will affect the athlete along with the change in these parameters.

\section{Method}

Exercise is one of the greatest stresses that the body is exposed to. In the study, how maximal training affected some biochemical parameters was investigated. The research was carried out on randomly selected 39 male and 11 female kick boxers who played at amateur level. The Ethics Committee (Frrat University Nr: 2017-00542) and each participant were informed and the approval form was signed. This study was carried out in accordance with the Helsinki Declaration. Blood samples from the antecubital vein were taken from the athletes by the healthcare professional into the gliotomy tubes $(4 \mathrm{ml}$ serum) before any training was performed. After the collection, the samples were incubated for 5 minutes, then centrifuged at $4500 \mathrm{rpm}$ for 5 minutes and stored at -20 until the analysis date. At the end of 30 minutes of free training, $4 \mathrm{ml}$ blood samples were taken from the athletes one by one and the procedure described above was applied. Then, GSH, TNF- $\alpha$, IL-1 $\beta$ and IL- 6 levels in the serum were examined by the ELISA method to determine the change of the training in the samples.

\subsection{Statistical Analysis}

The obtained data were evaluated as mean $\pm \mathrm{SD}$ and the Mann-Whitney $\mathrm{U}$ test was used to evaluate biological marker differences before/after training. The data obtained by statistical analysis below 0.05 of $\mathrm{P}$ value were considered significant.

\section{Results}

There is a total of amateur 50 athletes, consisting of 39 male and 11 female athletes, and demographic information about athletes, whose mean age is $20.08 \pm 6.33$ are given in Table 1 . Changes observed in GSH for both men and women, whereas IL-1B increased only in males $(p<0.05)$. There was no change in other parameters $(p>0.05)$. The changes in biochemical parameters for male and female were given separately in Table 2 as female and male. 
Table 1. Demographic Information about Athletes

\begin{tabular}{lccc}
\hline & Male & Female & $--P--$ \\
\hline Age & & $20.08 \pm 6.33$ & \\
BMI, kg/m & & $17.99 \pm 1.74$ & 0.023 \\
\hline
\end{tabular}

Data are presented as mean and standard deviation. Gender comparisons were carried out by Mann Whitney U test $(\mathrm{P}<0.05)$.

Table 2. Biochemical Changes in Athletes before and After Training

\begin{tabular}{|c|c|c|c|c|c|}
\hline MALE & MEAN & $\mathbf{N}$ & S.D & $\mathbf{t}$ & $\mathbf{P}$ \\
\hline GSH_INITIAL & 123.1 & 39 & 10.1 & \multirow{2}{*}{-3.294} & \multirow{2}{*}{0.00} \\
\hline GSH_FINAL & 128.5 & 39 & 7.34 & & \\
\hline IL6_INITIAL & 49.6 & 39 & 9.14 & \multirow{2}{*}{-1.557} & \multirow{2}{*}{0.12} \\
\hline IL6_FINAL & 52.7 & 39 & 10.1 & & \\
\hline IL1B_INITIAL & 133.7 & 39 & 24 & \multirow{2}{*}{-2.860} & \multirow{2}{*}{0.00} \\
\hline IL1B_FINAL & 165.6 & 39 & 60.1 & & \\
\hline TNFALFA_INITIAL & 289.1 & 39 & 52 & \multirow{2}{*}{1.713} & \multirow{2}{*}{0.09} \\
\hline TNFALFA_FINAL & 274.4 & 39 & 25.9 & & \\
\hline FEMALE & MEAN & $\mathbf{N}$ & S.D & $\mathbf{t}$ & $\mathbf{P}$ \\
\hline GSH_INITIAL & 118 & 11 & 9.45 & \multirow{2}{*}{-2.483} & \multirow{2}{*}{0.03} \\
\hline GSH_FINAL & 122.8 & 11 & 9.4 & & \\
\hline IL6_INITIAL & 50.8 & 11 & 8.78 & \multirow{2}{*}{0.708} & \multirow{2}{*}{0.49} \\
\hline IL6_FINAL & 49.2 & 11 & 5.58 & & \\
\hline IL1B_INITIAL & 128.5 & 11 & 19.5 & \multirow{2}{*}{-0.266} & \multirow{2}{*}{0.79} \\
\hline IL1B_FINAL & 131 & 11 & 19.5 & & \\
\hline TNFALFA_INITIAL & 279.3 & 11 & 27.4 & \multirow{2}{*}{0.089} & \multirow{2}{*}{0.93} \\
\hline TNFALFA_FINAL & 278.6 & 11 & 17.6 & & \\
\hline
\end{tabular}

\section{Discussion and Conclusion}

Physical activity is an important function of living systems. It affects many systems as well as hematologic and biochemical parameters. Hematologic and biochemical levels can also play an important role in the regulation of physiological responses such as adaptation to exhaustion, adaptation of cardiovascular activity and physical and physiological balance in humans (Arslan et al., 1997; Baltac1 et al., 1998). It has been shown that long-term exercise can have a positive effect on the lipid profile by lowering cholesterol and triglyceride levels and decreasing LDL-C levels. This effect is said to decrease total cholesterol and triglyceride levels by 0.5 and 0.7 mmol/l, respectively (Miguel, 2018). Hematologic and biochemical values during and after intense exercise can vary due to differences in the person's training status, gender, age, environmental conditions and nutrition. Hematologic changes have also been observed in the athletes due to long-term exercises (Beydağ1, 1998) In the study on 20 athletes carried out by Mello et al., a decrease in GSH concentration was observed (Mello, 2017). In another study, the effects of elite athletes on prooxidant/antioxidant status in different training were examined. 54 swimmers completed the training. Their nitrite, carbonyl and lipid peroxidation (LPO) levels were evaluated in the plasma. Enzymatic antioxidants, glutathione peroxidase (GPx) and glutathione reductase (GRd) and non-enzymatic antioxidants, total glutathione (GST), reduced glutathione $(\mathrm{GSH})$ ) and oxidized glutathione (GSSG) were analyzed in erythrocyte fraction. At the end of the study all groups showed an increase in LPO levels $(\mathrm{P}=0.001)$. It is seen that it worsened the antioxidant capacities and activated oxidative stress leading to cellular damage and the GSSG/GSH ratio seems to be associated with perceived effort and fatigue (León-López), 2018. Gill et al. found that there was an increase in IL-6 and IL-1B while evaluating the parameters of the effects of over-heat on stress in 2015 (Gill, 2015).

Future researches on physical, physiological characteristics of age, gender and kickboxing athletes' competitive levels are necessary to enrich existing knowledge and to help create a difference in metabolism. The effect of the fatty acids on the membrane structure of the cell membrane and its binding to the phospholipids in the cell membrane will in turn affect the activity of the enzymes controlling the production of the cytokines and the binding of the cytokines to the membrane receptors, in particular the change in the fluidity of the membranes and the change in cell membrane. From this point of view, a decrease in GSH levels was observed, whereas increases in the levels of TNF- $\alpha$, IL-6, and IL-1B are expected after physical activity.

In the present study, we observed changes in GSH in both males and females, while in IL-1B only in males. Because of the exercise observed in our study, it is seen that GSH is increased after training in both groups. We are of the opinion that increased GSH values are synthesized by the defense system as a necessity to prevent and eliminate free radical leaks after exercise. In line with this information, heavy exercise and stress are expected to show some metabolic 
changes in athletes. We found that the effect of the selected training program on athletes should be analyzed in terms of stress and metabolism and that an exercise to improve performance should be performed. Considering all biochemical parameters, it is seen that performing regular exercise has beneficial effects. In literature, although these parameters are less metabolic in kickbox athletes; while in our study, it can be said that more antioxidants are secreted to prevent oxidative damage after high effort and the defense system works actively.

As a result, the findings are within the normal range of change, except for changes in GSH and IL-1B, and therefore do not pose any risk to the athletes. However, it is recommended that such studies should be carried out frequently, with the possibility of encountering important findings in terms of human health or performance due to variables related to the environment or individual differences.

\section{References}

Abbas, A. K., Lichtman, A. H., \& Pober, J. S. (1994). Cellular and Molecular Immunology. 2nd Ed. Philadelphia, W.B.sounders.

Arslan, C., Bingölbalı, A., Kutlu, M., \& Baltacı, A. K. (1997). Voleybol ve atletizm sporunun kız çocukların hematolojik ve biyokimyasal parametrelerine etkisi, Bed Eğt Spor Bil Dergisi, 2, 28-34.

Atabek, H. Ç. (2009). Acute Lactate Production during Resistance Training. SPORMETRE Journal of Physical Education and Sport Science, VII(1), 29-36.

Aykın, A. G. (2010). Kick Boks Federasyonunun İdari ve Mali Yapısının İncelenmesi, Sosyal Bilimler Enstitüsü Spor Yöneticiliği Anabilim Dalı. Yüksek Lisans Tezi, Antalya: Akdeniz Üniversitesi.

Baltacı, A. K., Moğulkoç, R., Üstündağ, B., Koç, S., \& Özmerdivenli, R. (1998). Sporcu genç kızlarda bazı hematolojik parametreler ile plazma proteinleri ve serum çinko, kalsiyum, fosfor düzeyleri, Bed Eğt Spor Bil Derg, 3, 21-30.

Beydağı, H., Çoksevim, B., Temoçin, S., \& Akar, S. (1992). Akut submaksimal egzersizin spor yapan ve yapmayan kişilerde koagülasyona etkisi, Spor Hek Derg, 27, 113-119.

Bond, V., Adams, R. G., Tearney, R. J., et al. (1991). Effects of active and passive recovery on lactate removal and subsequent isokinetic muscle function. J. Sports Med. Phys. Fitness, 31, 357-61.

Callard, R., \& Gearing A. (1994). The Cytokine Facts Book. Orlando, Academic Press.

Çavuşoğlu, H. (1991). Egzersiz ve kan, İstanbul Tıp Fakültesi 11. Kurultayı Bildiri Kitabı, 249-252.

Gill, S. K., Teixeira, A., Rama, L, Prestes, J., Rosado, F, Hankey, J., ... Costa, R. J. (2015). Circulatory endotoxin concentration and cytokine profile in response to exertional-heat stress during a multi-stage ultra-marathon competition. Exerc Immunol Rev., 21, 114-128. http://www.drmuratkeklikoglu.com

Karadağ, M. (2017). Compare the Values of Blood Lactate and Heart Rate of Kickboxers during Kickboxing Matches. Journal of Education and Training Studies, 5(7), July. https://doi.org/10.11114/jets.v5i7.2317

Konukoğlu, D., \& Akçay, T. (1995). Glutathione metabolism and clinical importance, Türkiye Klinikleri J Med Sci; 15(4), 214-218.

León-López, J., Calderón-Soto, C., Pérez-Sánchez, M., Feriche, B., Iglesias, X., Chaverri, D., ... Salerno, V. P. (2017). Oxidative stress and antioxidant biomarker responses after a moderate-intensity soccer training session, Res Sports Med., Jul-Sep; 25(3), 322-332.

Miguel, A., Julien, V., \& Olivier, G. (2018). Impact of long distance rowing on biological health: A pilot study, Clinical Biochemistry, 52, 142-147. https://doi.org/10.1016/j.clinbiochem.2017.11.018

Ouergui, I., Hssin, N., Franchini, E., Gmada, N., \& Bouhlel, E. (2013). Technical and tactical analysis of high-level kickboxing matches. Int. J. Perform Anal. Sport, 13(2), 294-309. https://doi.org/10.1080/24748668.2013.11868649

Rodréguez, F. A. (2018). Oxidative stress in elite athletes training at moderate altitude and at sea level. Eur. J Sport Sci., Mar 24, 1-10.

Rosa, M. S., \& Pinto, A. M. (2006). Cytokines. In: Burtis CA, Ashwood ER, Bruns DE. Eds. Tietz textbook of clinical chemistry and molecular diagnostics, 4 th Ed. Missouri: Elsevier Saunders; 645-744.

\section{Copyrights}

Copyright for this article is retained by the author(s), with first publication rights granted to the journal.

This is an open-access article distributed under the terms and conditions of the Creative Commons Attribution license which permits unrestricted use, distribution, and reproduction in any medium, provided the original work is properly cited. 